\title{
Informal Economy And Economic Growth In Cameroon
}

\author{
EHODE ELAH Raoul, Ph.D. EHODE \\ ehoderaoul@yahoo.fr \\ Head of Department of Economic Studies \\ and Environmental (EAD) \\ Member of the Academy of Young Scientists of Cameroon \\ National Education Centre/ \\ (CNE/MINRESI) \\ TOURERE ZENABOU , Ph. D \\ ze_na_bour@yahoo.fr \\ Faculty of Economics and Applied Management \\ University of Yaoundé II Soa \\ DOI: 10.29322/IJSRP.10.05.2020.p10159 \\ http://dx.doi.org/10.29322/IJSRP.10.05.2020.p10159
}

\begin{abstract}
The informal economy is characterized by low productivity and does not promote diversification into higher productivity sectors. Its weight in the economy and employment in low-income countries, particularly on the African continent, makes it a priority for the international community in terms of development. Indeed, the results of the 2005 NSI Employment and Informal Sector Survey (EESI) describe a situation of widespread underemployment and computerization of 75.8 per cent and 90.4 per cent respectively. In Cameroon, about $90 \%$ of jobs are informal (INS, 2005, 2011). In view of this observation, the question may be asked: what is the link that can be established between the informal economy and economic growth? The objective of this paper is to examine the correlation between the informal economy and economic growth. Our analyses are based on data from the Second Employment and Informal Sector Survey (EESI 2) conducted by the National Statistical Institute (NSI) and on the existing theoretical and empirical literature review. The results show that: the informal economy is a hindrance to the realization of economic growth potential in the countries (I), and that strong, sustainable and inclusive growth is necessary to reduce the size of the informal economy (II).
\end{abstract}

Key words : infomal, economics income

\section{I- Introduction}

Since its emergence in developing countries in the 1970s, the Informal economy has grown to become a sector absorbing unemployment in these countries (ESSI2, 2010). From this perspective, most jobs in developing countries (DCs) are in the informal economy, which plays a predominant role in the economy. Thus, the global economic crisis of the 1980s and structural adjustment policies are thought to have increased the weight of the informal economy in this part of the world, due to job losses in the formal sector and reduced hiring capacities in other sectors of economic activity (CLING et al., 2012). However, the informal economy, or informal sector, refers to all activities producing goods and services that are not regulated by the State. These activities are found in all sectors (primary, secondary and tertiary). In the majority of African countries, the informal sector occupies an important place in the economy. This sector is indispensable for the fight against poverty, which is at the heart of the concerns of development policies. It is a major issue from the political, economic and social point of view (Cling et al, 2012). Despite the advantage that this sector represents for social stability, the vagueness that continues to surround the informal economy remains an obstacle and hinders its consideration by economic policies and national accounting. This makes it difficult 
to make this sector a lever for growth. Despite its productivity and contribution to GDP, the enterprises operating in the informal economy are not registered but produce goods and services for the market.

On the other hand, informal employment is defined as unprotected employment (Cling et al., 2012). From this point of view, the sector is outside government control and operates on the margins of labour market regulation: firms operate on the margins of the economy and do not pay taxes (ILO, 2003). However, the growth dynamics observed in the majority of African countries over the past decade have not led to a significant decline in the informal sector's place in the economies.

Indeed, according to François Perroux (1968), economic growth corresponds to "the sustained increase over one or more long periods of time of an indicator of the size, for a nation, of the net global product in real terms". The informal sector, which employs a large part of the active population, and given its size, should be able to effectively support the country's development. However, it is beyond the control of the authorities and constitutes a loss of revenue for the country concerned.

Although Cameroon has recorded positive growth rates since the mid-1990s, the rate of informality in the country stands at $88.6 \%$ in 2014 against $90.3 \%$ in 2007, and the poverty rate has remained relatively high at 37.5\%, (INS, 2015) in ECAM 4). The growth rates recorded have never reached the $7 \%$ level necessary according to NEPAD to significantly reduce poverty. In view of this observation, the question arises as to what is the link that can be established between the informal economy and economic growth. The objective of this article is to examine the correlation that exists between the informal economy and economic growth in Cameroon. On the basis of the existing literature review, both theoretical and empirical, we will try to show on the one hand that the informal economy is a brake on the realization of the economic growth potential in the countries (I), and that strong, sustainable and inclusive growth is necessary to reduce the importance of the informal economy (II).

\section{I- The informal economy is a brake on the realisation of economic growth potential}

The economic literature on the informal economy shows that a country cannot build a sustainable growth strategy on the informal sector although the latter can have positive effects on the growth process.

\section{I.1: The informal economy, GDP formation and growth dynamics.}

Despite four decades of research, no consensus has emerged on the origin and persistence of the informal sector. A long tradition, namely the "dualist school", considers the informal sector to be the least advantageous segment of the labour market (Lewis, 1954; Harris and Todaro, 1970; Pradhan, 1995). From this perspective, informal entrepreneurship is the result of the saturation of the formal sector (Nana et al, 1914). A more recent approach views the informal sector as a set of dynamic small enterprises, where individuals choose to become informal entrepreneurs because they expect higher welfare than if they were formal employees or entrepreneurs (Maloney, 2004; Packard, 2007). In this approach, a significant share of informal self-employment may reflect an efficient division of labour. Seen From this perspective, the informal economy can contribute to the formation of GDP and the maintenance of a growth dynamic in situations of crisis, ineffective economic policies and high population growth. This specific role of the informal economy can be examined through its capacity to create precarious jobs, support the formal sector and its contribution to peace.

\section{I.1.1: The creation of precarious jobs in the informal sector}

The informal sector accounts for nearly a quarter of total employment and is the main source of non-agricultural employment (half of non-agricultural employment). Although the socio-economic characteristics of the labour force employed in the informal 
sector are close to the national average, the attributes of the jobs are very different and generally of lower quality than in other sectors (excluding agriculture). In a country like Vietnam, the wage rate is low (27\%) and the forms of employment are much more precarious: more than $99 \%$ have at best a verbal contract (25\% have no contract at all), compared to only $3 \%$ in the public sector; $10 \%$ are paid monthly (which is the norm in other sectors), the majority being paid on a daily, hourly, piecework or commission basis. For all workers in this sector, the rate of social security coverage is negligible ( 0.1 per cent), although it reaches 87 per cent (Cling et al., 2012).

Informal sector workers have the lowest wages outside agriculture, which is related to their low level of education. It can be assumed that almost all jobs in the informal sector are carried out without specific work premises (at home or on the street), which is another indicator of the precariousness of work in this sector (Cling et al., 2010a). On the other hand, the informal sector accounts for more than $50 \%$ of overall GDP value added in low-income countries, more than $80 \%$ of total employment and more than $90 \%$ of newly created jobs in these countries. It therefore has strong implications for employment opportunities, productivity, tax revenues and economic growth (OIF, 2014). By creating significant precarious jobs, the informal sector thus favours the distribution of income to a large part of the population. This income is used to consume local goods, thereby supporting growth according to the Keynesian Multiplier logic. With the government's strategy of supporting informal production units, it can be seen that despite the lack of regulation in the informal sector, it makes a significant contribution to reducing unemployment. It therefore seems obvious that

that formalization would improve the productivity of these production units and their standard of living. According to Englander and Gurney (1994), productivity growth is the foundation for improvements in real incomes and welfare. Slow productivity growth limits real income growth and increases the potential for conflicts over income redistribution. Support in this direction can boost the level of productivity in the sector. Tables 1 and 2 below show the potential of the informal sector in Cameroon to capitalize to improve the labour market and thereby the living conditions of the target populations.

Table 1: Productivity of IPUs by branch of activity according to average remuneration of workers in the IPU in Cameroon 


\begin{tabular}{|c|c|c|c|c|c|c|c|c|}
\hline & \multicolumn{4}{|c|}{ Rémunération moyenne des travailleurs } & \multicolumn{3}{|c|}{$\begin{array}{c}\begin{array}{c}\text { Revenu horaire moyen des } \\
\text { travailleurs }\end{array} \\
\end{array}$} & \multirow[t]{2}{*}{ Ensemble } \\
\hline & $\begin{array}{l}\text { Moins de } \\
30000 \mathrm{~F}\end{array}$ & $\begin{array}{c}30000 \text { à } \\
50000\end{array}$ & $\begin{array}{l}51000 \text { à } \\
100000\end{array}$ & $\begin{array}{l}\text { Plus de } \\
100000\end{array}$ & $\begin{array}{l}\text { Moins de } \\
200 \mathrm{~F} / \mathrm{h}\end{array}$ & $\begin{array}{l}\text { Entre } 200 \\
\text { et } 300 \mathrm{~F} / \mathrm{h}\end{array}$ & $\begin{array}{l}\text { Plus de } \\
300 \mathrm{~F} / \mathrm{h}\end{array}$ & \\
\hline \multicolumn{9}{|l|}{ Branche d'activité } \\
\hline Industrie & 87 & 283 & 650 & 1637 & 85 & 318 & 1179 & 487 \\
\hline Agro-alimentaire & 107 & 292 & 579 & 2136 & 91 & 292 & 1111 & 280 \\
\hline Confection & 47 & 325 & 1108 & 1438 & 59 & 406 & 1294 & 321 \\
\hline Autre industrie & 100 & 262 & 503 & 1309 & 108 & 299 & 1118 & 704 \\
\hline BTP & 166 & 246 & 489 & 2129 & 142 & 255 & 1238 & 894 \\
\hline Commerce & 90 & 242 & 599 & 1447 & 94 & 335 & 1236 & 479 \\
\hline Commerce de gros & 110 & 420 & 2244 & 2391 & 136 & 247 & 2510 & 1754 \\
\hline Commerce de détail & 89 & 234 & 435 & 1124 & 92 & 339 & 912 & 347 \\
\hline Services & 101 & 252 & 451 & 1085 & 118 & 281 & 906 & 422 \\
\hline Transport & 108 & 207 & 513 & 1210 & 126 & 255 & 1045 & 552 \\
\hline Restauration & 105 & 338 & 390 & 978 & 115 & 270 & 792 & 359 \\
\hline Réparation & 73 & 187 & 425 & 773 & 86 & 493 & 589 & 246 \\
\hline Autres services & 108 & 264 & 445 & 1110 & 134 & 267 & 952 & 449 \\
\hline \multicolumn{9}{|l|}{ Milieu de résidence } \\
\hline Urbain & 99 & 247 & 496 & 1244 & 106 & 329 & 980 & 477 \\
\hline Industrie & 106 & 275 & 683 & 1435 & 109 & 344 & 1042 & 542 \\
\hline Commerce & 88 & 221 & 431 & 1416 & 102 & 376 & 1147 & 466 \\
\hline Services & 108 & 247 & 401 & 1017 & 109 & 293 & 826 & 442 \\
\hline Rural & 86 & 275 & 653 & 1631 & 90 & 258 & 1324 & 444 \\
\hline Industrie & 79 & 292 & 533 & 1800 & 73 & 265 & 1350 & 442 \\
\hline Commerce & 93 & 266 & 951 & 1495 & 85 & 254 & 1356 & 497 \\
\hline Services & 92 & 263 & 544 & 1432 & 129 & 256 & 1210 & 384 \\
\hline Ensemble & 92 & 258 & 544 & 1385 & 98 & 305 & 1103 & 463 \\
\hline
\end{tabular}

Source : INS, EESI 2, 2010

Table 2: Productivity of IPUs by sector of activity according to average age of workers in the IPU in Cameroon

\begin{tabular}{|c|c|c|c|c|c|c|c|c|}
\hline & \multicolumn{7}{|c|}{ Age } & \multirow{2}{*}{ Ensemble } \\
\hline & $\begin{array}{l}\text { Moins de } 25 \\
\text { ans }\end{array}$ & $25-29$ ans & $30-34$ ans & $35-39$ ans & $40-44$ ans & $45-49$ ans & $\begin{array}{c}50 \text { ans ou } \\
\text { plus }\end{array}$ & \\
\hline \multicolumn{9}{|c|}{ Secteur d'activité } \\
\hline Industrie & 156 & 388 & 727 & 914 & 400 & 224 & 405 & 487 \\
\hline Commerce & 348 & 541 & 480 & 426 & 637 & 723 & 373 & 479 \\
\hline Services & 275 & 372 & 493 & 529 & 633 & 638 & 446 & 422 \\
\hline \multicolumn{9}{|c|}{ Milieu de résidence } \\
\hline Urbain & 323 & 458 & 503 & 592 & 553 & 498 & 510 & 477 \\
\hline Rural & 185 & 378 & 730 & 681 & 582 & 612 & 283 & 444 \\
\hline Ensemble & 249 & 428 & 583 & 630 & 566 & 554 & 398 & 463 \\
\hline
\end{tabular}

Source: INS, EESI 2, 2010

\section{I.1.2: Support of the formal economy by the informal economy}

This publication is licensed under Creative Commons Attribution CC BY. 
By setting up in the informal sector, companies can grow their business. As a result, in order to remain in compliance with the tax regulations of the country in which it is located, it is called upon to migrate to the formal sector: to regularize its activities in accordance with the laws and regulations of the labour market of the country concerned. Thus, enterprises in the informal sector that reach a certain level of capital accumulation migrate to the formal sector by setting up modern enterprises. It can therefore be assumed that savings from informal sector activities will be recycled into the traditional banking system. They thus contribute to the distribution of credit for investment or consumption activities in the formal sector. On the other hand, savings from informal financial systems are used for investment in the formal sector.

Moreover, in Cameroon, the level of annual investments in this sector in 2010 was close to CFAF 100 billion. Non-agricultural informal production units (IPUs) are mostly in the trade and services sector (65.8). The Government's current policy, set out in the Growth and Employment Strategy Paper (DSCE), addresses the issue of migration of IPUs to the formal sector through strategies including training, with the aim of helping these actors to better monitor their activities through light bookkeeping and assistance with installation and financing. This idea translates into the creation of support projects for the informal sector (PIAASI, FNE, PAJER-U, PIFMAS, etc.) and the accompaniment of promoters through the financing granted to them (ESSI 2, 2010).

\section{I.1.3: The contribution of the informal economy to peace.}

The informal sector accounts for $90 \%$ of the active population in Cameroon. This situation, which is not peculiar to Cameroon, contributes considerably to the national stability of the countries. By contributing to social peace, which is a factor of growth, the informal sector constitutes through this channel a source of subsistence and employment for a significant fringe of the population. As such, we will meet actors in the sector who do not wish to transfer to the formal sector. As soon as an individual is able to carry out his or her activity, he or she lives in a situation of total calm. This situation is in line with the following assertion: "work keeps boredom, vice and need away from man". Through this understanding of the notion of informal work, the informal sector leads each individual to a paid occupation. Although precarious, the informal sector has succeeded where the formal sector has failed.

\section{I.2 the informal economy: a hindrance to the realization of economic growth potential}

\section{I.2.1: the loss of earnings creates}

The informal economy creates a shortfall in public finances, limiting public investment, which is an important determinant of growth. In fact, the dual nature of most African economies, characterized by a large informal sector that escapes payment of taxes, can be an obstacle to sustainable growth, and the formal sector, reduced to its simplest form and comprising mainly private foreign investment, which has to bear a completely disproportionate tax burden, undermines economic competitiveness. In contrast to the formal sector, the contribution of the informal sector to tax collection contrasts sharply with its share in overall value added. Benjamin and Mbaye (2012a) note that in francophone West African countries, large formal enterprises contribute more than $95 \%$ of tax collection, while the informal sector contributes less than 3\%, contrasting with its more than $50 \%$ contribution to overall value added (OIF, 2014).

Recent economic literature highlights the role of the "moral tax", considered as an important determinant of the extent of tax evasion and, more generally, of informality (Perry et al. 2007). This notion refers to the perceived level of honesty and fairness of the tax system and the judicious use of tax revenues by the state. In Latin America, for example, it has been found that countries in which taxpayers are confident in the sound management of public funds, collection levels are also higher (Benjamin and Mbaye, 2012a). This conclusion is strongly corroborated in West Africa by the work of Benjamin and Mbaye (2012a), who found that countries with the lowest level of satisfaction with the management of public resources are also those with the highest level of tax evasion. With the growing number of informal production units, the volume of tax losses is also significant (OIF, 2014, Anastasia Giardinelli, 2019).

\section{I.2.2: The low productivity of the sector}


The informal economy is characterized by low productivity and does not promote diversification into higher productivity sectors (IFM, 2014). The weight of the informal sector in the economy and employment of low-income countries, particularly in Africa, makes it necessary to place it among the development priorities of the international community. Its many consequences in terms of productivity, competitiveness, business environment and quality of employment opportunities make it one of the major obstacles to the diversification of these economies towards more productive activities in the agricultural and industrial sectors, and to their integration into regional and international value chains. Studies have shown that there is a strong correlation between basic vocational qualifications and labour force performance. Thus, the best-trained workers tend to be those who achieve higher levels of productivity and income. This correlation remains true in the informal sector, despite the low levels of profitability observed there. Moreover, the gap in productivity and substantial gains observed between formal and informal sector firms, in Africa as elsewhere, supports this view of worker qualification and performance (OIF, 2014). Roubeaud and Torelli (2013) estimated that the wage level in the formal economy is twice as high as in the informal economy in Cameroon and the DRC, 3 times in Senegal, and 3.6 times in Côte d'Ivoire (OIF, 2014).

\section{I.2.3: the basis of precarious employment}

The informal economy creates precarious employment and the majority of workers in the informal sector are poor. This makes it impossible to sustain growth through consumption and can lead to political instability, which is detrimental to economic growth. Because activities in the sector are excluded from the law or fall outside the framework of regulation and taxation, employees in the sector offer jobs under conditions that are outside the scope of the labour code in Cameroon. The development of such practices has been accentuated by the fact that since 1970, the informal sector has been "made up of small-scale economic activities, composed of self-employed people using family labour or a few workers" (ILO, 1991). In addition, promoters often justify the payment of low wages by the possession of little capital, the use of low-level technology and lack of access to financial markets (ILO, ND).

\section{I.2.4: Low income generation}

The income generated by the informal sector remains, for the most part, insufficient for real savings to support productive investment and thus strong growth. The informal economy is a situation that is just as "compliant" as the formal economy and can be considered as an emerging institution. It constitutes insufficiently institutionalized formal institutions. In the economy, spontaneous collective action that is not institutionalized is referred to as the "informal economy". The informal economy in developing countries is an economy of survival and poverty and indispensable, which mixes the social network, family and the small size of the activity. As Bangbola (2003) points out, "the informal economy is more than an avatar of the formal economy before spilling over into it. It is a specific form of economic structuring in developing countries that focuses on the different roles played by micro and small enterprises and their capacities to generate subsistence, income and growth adapted to the local and national market. But the analysis would be incomplete if it did not take into account, although this aspect is little asserted and studied, the possible role of the informal sector as a low-cost subcontractor of modern sector enterprises. Structural adjustment programmes have, in fact, placed the latter in a context of seeking greater competitiveness and have, in a way, encouraged them to resort to the actors of this economy to make their production processes more flexible and reduce their costs.

\section{II- Strong, sustainable and inclusive growth is needed to reduce the size of the informal economy}

Reducing the size of the informal sector, which limits the realization of countries' growth potential, requires identifying the causes of underdevelopment and tackling it while creating the conditions for strong, sustainable and inclusive growth. For strong, sustainable and inclusive growth can reduce the size of the informal economy.

\section{II.1 The need to reduce the attractiveness of the informal sector.}

Reducing the attractiveness of the informal sector will have several effects for private economic agents. Thus, these effects will be perceptible among job seekers and investors.

As far as job seekers are concerned, strong, sustainable and inclusive growth makes it possible to create decent jobs in sufficient quantities in sectors with high growth potential (agriculture, manufacturing industry, high value-added services (tourism, 
telecommunications, etc.), thus absorbing a large part of the under-utilized labour force in the informal sector. Moreover, this growth raises the level of education, as many households rise out of poverty due to a better distribution of income and investment in the education of their children, whose employment opportunities in the formal sector are increasing.

For businesses, strong, sustainable and inclusive growth will lead to :

The improved business climate necessary for growth may make the informal sector less attractive to entrepreneurs.

The increase in the size of the informal economy reduces profit opportunities in the formal sector.

\section{II.2.2 increasing the financial capacity of the State.}

Increasing the financial capacity of the State through better collection of fiscal resources. Thus, several opportunities are offered to the State. It can therefore invest in infrastructure that will reduce the production costs of enterprises in the formal sector. In addition, the State can invest in the education and health sectors that will improve the productivity of the factors that can seize new opportunities (employment and/or business) in the formal sector. The statistical definition of the informal economy was adopted at the International Conference of Labour Statisticians in January 1993 in order to allow statistical observation in countries where informal micro and small enterprises play an important role in terms of employment and contribution to GDP, so as to require the specific consideration of the sector in macroeconomic modelling and sectoral policies without having access to figures. According to this definition, the informal sector is a subset of the institutional household sector in national accounts. Enterprises in the informal economy are therefore made up of :

Family enterprises or "informal enterprises of own-account workers" (these are enterprises that do not employ employees on a continuous basis, but may employ family helpers and/or casual workers), Micro-enterprises or "informal employers' enterprises" that employ one or more employees on a continuous basis.

\section{Conclusion}

The informal economy can contribute to the formation of GDP and the maintenance of a growth dynamic in situations of crisis, ineffective economic policies and high population growth. It cannot, however, enable a country to realize its economic growth potential with regard to the factors of production and the resources at its disposal. Rather, the informal economy appears to be a perverse effect of low growth rates resulting from poor economic policies and high population growth. Only strong, sustainable and inclusive economic growth can limit the place of the informal economy in countries, realize its growth potential and put it on a path of harmonious economic development in the long term.

\section{BIBLIOGRAPHY}

Anastasia Giardinelli (2019): Economy, Informal Economy, Jobs and Growth in Sub-Saharan Africa, Calenda, Published on Monday 01 July by

François Perroux (1968): "Multinational investments and analysis of development poles and integration poles" Third World Review Year 34 pp. 239-265

ROUBAUD FRANÇOIS (2002): Identities and Democratic Transition: The Malagasy Exception, Revue Tiers Monde Year 172 pp. 952-953, Part of a thematic issue: Microfinance: Small Amounts, Big Effects?

CLING Jean-Pierre, LAGRÉE Stéphane, RAZAFINDRAKOTO Mireille and ROUBAUD François (2012): The informal economy in developing countries ", conference and seminar 06, AFD

CLING, J.-P., NGUYEN THI THU HUYEN, NGUYEN HUU CHI, PHAN THI NGOC TRAM, M. RAZAFINDRAKOTO and F. ROUBAUD (2010a), The Informal Sector in Vietnam: A Focus on Hanoi and Ho Chi Minh City, Editions the Gioi, Hanoi.

OIF (2014): ""The Role of the Informal Sector for Growth, Employment and Sustainable Development," Reflections, Informal Sector, Jobs and Transformation structural: Operational recommendations for an effective policy towards the informal sector

INS, EESI2 (2010): "Productivity in the informal sector in Cameroon". 
MBAYE, A.A. (2005): 'Sanitary and Phytosanitary Requirements and Developing Country Agro Food exports: An Assessment of the Senegalese Groundnut Sector'. World Bank Agriculture and Rural Development Discussion Paper. Washington, DC: World Bank.

GOLUB, S.S. and J. McMANUS (2008): 'Horticulture Exports and African Development'. Paper prepared for UNCTAD. Mimeo.

BRENTON, P., R. NEWFARMER, and WALKENHORST P. (2009): 'Avenues for Export Diversification: Issues for LowIncome Countries'. MPRA, Commission on Growth and Development Working Paper 47. Munich: MPRA.

DINH, H.T., V. PALMADE, V. Chandra, and F. Cossar (2012) :Light Manufacturing in Africa: Targeted Policies to Enhance Private Investment and Jobs. Washington, DC: World Bank.

BENJAMIN N., S. GOLUB, and A. A. MBAYE (2014): 'Informality, Regional Integration and Smuggling in West Africa'. Forthcoming in Borderland Studies.

BENJAMIN N., and MBAYE A.A. (2012a): 'The Informal Sector in Francophone Africa: Firm Size, Productivity and Institutions'. Washington, DC: World Bank. 2 Benjamin N., and MBAYE A.A. (2012b). Informality, Productivity, and Enforcement in West Africa: A Firm-Level Analysis'. Review of Development Economics.

Pr YVON PESQUEUX - Chair (2005): 'From the informal economy', CNAM, France Department of Management, Innovation, Prospective 